\title{
Huishoudens en persoonlijke netwerken
}

\author{
Sarah Westphal, Gerald Mollenhorst \& Beate Völker
}

MEM 89 (1): 59-84

DOI: $10.5117 / M E M 2014.1 . W E S T$

\section{Summary \\ Households and personal networks}

We investigate the association between household arrangements and social network characteristics by using three structural perspectives: social context, time demands, and social support. Evidence from the Survey on the Social Networks of the Dutch 2007/2008 (SSND; N = 950) best supports the social support and time demands perspectives. While persons living in households with a partner and/or with children generally hold fewer and less diverse ties to household externals with whom they discuss important personal matters; those living alone have larger core discussion networks with more different contacts. This suggests that those living alone are not less socially integrated than people who share a household with others.

Keywords: household arrangements, personal relationships, social networks, social integration

\section{Inleiding}

Onderzoek op het gebied van demografie en familiesociologie heeft aangetoond dat in westerse samenlevingen gedurende de afgelopen decennia de gangbare samenstellingen en vormen van huishoudens significant zijn veranderd. Cijfers van het Centraal Bureau voor de Statistiek (CBS) laten een gestage toename zien van het aantal echtscheidingen, eenoudergezinnen, ongehuwd samenwonenden en eenpersoonshuishoudens sinds het begin van de jaren tachtig van de vorige eeuw (De Hart e.a., 2002; Rijken \& Liefbroer, 2011). Deze voortdurende ontwikkelingen suggereren dat nieuwe huishoudens- en relatievormen steeds wijdverbreider worden (De Graaf, 2011). Dit leidt tot vragen over de invloed van deze ontwikkelingen op individuele persoonlijke netwerken, aangezien in de wetenschappelijke 
literatuur het huwelijk en het hebben van een partner vaak gezien wordt als een belangrijke basis voor het ontvangen van sociale steun, informatie, gezelschap en sociale integratie in de samenleving (zie bijvoorbeeld Waite \& Gallagher, 2000).

In bestaand onderzoek naar de invloed van huishoudensvorm op netwerksamenstelling en -structuur werd huishoudensvorm vaak gemeten in termen van de huwelijkse staat van de respondent, geclassificeerd als 'nooit gehuwd geweest', 'gehuwd', 'gescheiden', of 'verweduwd' (Terhell, 2003). Bij dit meetinstrument kunnen echter vraagtekens geplaatst worden. Onderzoek van Kalmijn (2003) naar gedeelde vriendschappen over de levensloop laat bijvoorbeeld zien dat de gevolgen van veranderingen in huishoudensvormen voor persoonlijke netwerken voornamelijk toe te schrijven zijn aan een veranderde samenstelling van huishoudens. Tot op heden is overigens nog maar weinig onderzoek gedaan naar de invloed van huishoudensvormen op kenmerken van persoonlijke netwerken. Bovendien is in onderzoek op het gebied van de sociale integratie van mensen uit verschillende huishoudensvormen (bijvoorbeeld Alwin, Converse \& Martin, 1985) weinig aandacht besteed aan theoretische verklaringen voor de relatie tussen huishoudensvormen en netwerkkenmerken.

Om deze beperkingen teniet te doen brengen we in deze bijdrage onderzoek samen op het gebied van sociale netwerken en de familiesociologie. Aan de hand van de 'keuze-beperking benadering' (Fischer, 1982) leveren we een bijdrage aan de onderzoeksliteratuur, waarbij we ons niet richten op huwelijkse staat, maar op de omvang en samenstelling van huishoudens als mogelijke drijvende kracht achter veranderingen in netwerkkenmerken. Volgens de 'keuze-beperking benadering' kunnen huishoudensvormen gezien worden als structurele beperkingen, die van invloed zijn op de contactmogelijkheden die een individu heeft. Op basis van deze benadering kunnen we drie verschillende argumenteringslijnen afleiden die de relatie tussen huishoudensvorm en netwerkkenmerken mogelijk verklaren. Ten eerste, volgens het 'sociale contexten perspectief' vergroot de aanwezigheid van huishoudleden de contactmogelijkheden van het individu met anderen buiten het huishouden. Ten tweede, volgens het 'tijdinvesteringsperspectief' is de relatie tussen huishoudensvorm en netwerkkenmerken deels een gevolg van beschikbare tijd. Ten derde, volgens het 'sociale steun perspectief' is de behoefte aan gezelligheid en steun de drijvende kracht achter de relatie tussen huishoudensvorm en netwerkkenmerken. Tot dusver zijn deze perspectieven niet wederzijds exclusief onderzocht - conceptueel niet, maar ook niet wat betreft de meting ervan. Mogelijk vinden we om die reden in de literatuur voor alle drie de perspectieven empirische ondersteuning. Een 
van de doelen van onze studie is daarom licht te werpen op de implicaties van de drie genoemde perspectieven en te onderzoeken voor welk van deze perspectieven we de meeste empirische ondersteuning vinden.

Maar wat is nu eigenlijk een huishouden en hoe definiëren we een netwerk? In dit onderzoek beschouwen we een huishouden als bestaande uit a) een individu, b) een individu en haar/zijn partner, c) een individu, een partner en (een) kind(-eren), of d) een individu en (een) kind(-eren). Natuurlijk zijn er ook andere huishoudensamenstellingen mogelijk, zoals huishoudens met grootouders of andere familieleden, maar deze zijn relatief zeldzaam in Nederland. Dergelijke samenstellingen komen daarom ook te weinig voor onder onze respondenten die een representatieve afspiegeling vormen van de Nederlandse bevolking in de leeftijd van 18 tot 70 jaar. Wat het persoonlijk netwerk betreft kijken we in deze studie specifiek naar de relaties tussen de respondenten en personen buiten hun huishouden met wie zij het afgelopen half jaar belangrijke persoonlijke zaken hebben besproken. In het vervolg van dit artikel noemen we deze personen 'discussiepartners', die samen iemands 'kernnetwerk' vormen, zonder daarbij telkens te benoemen dat het daarbij gaat om discussiepartners die niet tot het huishouden van de respondent behoren. Dergelijke doorgaans sterke bindingen met discussiepartners worden gekarakteriseerd door grote tijdsinvesteringen, emotionele nabijheid en sociale steun en geven een gevoel erbij te horen (Granovetter, 1973). Indien we ervan uitgaan dat relaties met huishoudleden deze kenmerken van sterke relaties delen, dan mogen we verwachten dat de rol en functie van huishoudleden competitief is met de rol en functie van discussiepartners buiten het huishouden en als gevolg daarvan dat veranderingen in huishoudensamenstelling van grote invloed zijn op sterke relaties buiten het huishouden, meer dan op zwakkere relaties.

In deze studie toetsen we de hypothesen die we afleiden van de genoemde drie structurele perspectieven aan de hand van data van de Survey on the Social Networks of the Dutch (SSND, 2007/2008; Völker, Flap \& Mollenhorst 2008). Deze dataset bevat gedetailleerde informatie over zowel de huishoudensvorm en -samenstelling als de omvang en samenstelling van de persoonlijke netwerken van een steekproef van 998 respondenten die representief zijn voor de Nederlandse bevolking in de leeftijd van 18 tot 70 jaar. 


\section{Theorie en hypothesen}

Volgens de 'keuze-beperking benadering' van Fischer (1982) wordt met wie iemand omgaat, met wie iemand bevriend raakt en zelfs met wie iemand trouwt, niet zuiver bepaald door individuele voorkeuren en keuzes, maar sterk beïnvloed door condities waarop het individu zelf weinig of geen invloed heeft. Relaties aangaan is slechts mogelijk met diegenen die iemand in het dagelijks leven ontmoet en de range van potentiële interactiepersonen die iemand ontmoet, wordt geconditioneerd door de sociale structuur waarin hij of zij is geplaatst (Fischer, 1982). Deze plaats in de sociale structuur beïnvloedt echter niet alleen het aangaan van relaties, maar ook de instandhouding ervan. Persoonlijke en sociale omstandigheden, zoals financiële hulpbronnen en het verrichten van betaalde arbeid, bieden en vormen verschillende mogelijkheden en beperkingen voor het aangaan en onderhouden van vriendschappen en andere sociale contacten (Moore, 1990). Dergelijke aspecten van de sociale structuur beïnvloeden daarmee de mogelijkheden om persoonlijke relaties te vormen en onderhouden. Persoonlijke relaties en netwerken kunnen daarom gezien worden als 'the result of individual choices made within social constraints' (Fischer, 1977: 42). Huishoudensvorm en -samenstelling kunnen ook gezien worden als structurele beperkingen die de mogelijkheden voor contacten binnen en buiten het huishouden mede vormgeven en daarmee persoonlijke relaties en netwerken mede bepalen. De zorg voor kinderen kan bijvoorbeeld iemands behoefte aan hulp en steun van bloedverwanten vergroten, terwijl samenwonen met een partner de beschikbare tijd om met andere vrienden uit te gaan mogelijk beperkt.

Aan de hand van de 'keuze-beperking benadering' kunnen we vervolgens drie verschillende argumenteringsperspectieven afleiden, of mechanismen formuleren die de relatie tussen huishoudensvorm en netwerkkenmerken mogelijk verklaren.

1. Sociale contexten perspectief: huishoudensvorm en -samenstelling beïnvloeden persoonlijke netwerken, omdat zij contactmogelijkheden mede bepalen;

2. Tijdinvesteringsperspectief: huishoudensvorm en -samenstelling beïnvloeden persoonlijke netwerken, omdat zij mede iemands beschikbare tijd bepalen;

3. Sociale steun perspectief: huishoudensvorm en -samenstelling beïnvloeden persoonlijke netwerken, omdat zij mede de behoefte aan hulp en sociale steun bepalen. 
We evalueren deze perspectieven indirect door de relatie te onderzoeken tussen huishoudensvorm en -samenstelling enerzijds en de omvang en samenstelling van het netwerk van personen met wie men belangrijke persoonlijke zaken bespreekt anderzijds. Grote netwerken met verschillende typen netwerkleden (zoals bloedverwanten, vrienden, buren en collega's) worden veelal gezien als teken van sociale integratie en toegang tot sociale steun. Het onderzoeken van zowel de omvang als de samenstelling (of diversiteit) van deze kernnetwerken biedt een eerste inzicht in de manier waarop huishoudenssamenstellingen van invloed zijn op de omvang en variëteit van nabije sociale contacten van individuen. De evaluatie van de drie genoemde theoretische perspectieven biedt bovendien inzicht in mogelijke verklaringen voor het verband tussen huishoudens en netwerken. Op grond van eerder onderzoek mogen we verwachten dat de verschillende verklaringen opgaan voor relaties van uiteenlopende sterkte (zie bijvoorbeeld Mollenhorst, Völker \& Flap, 2008). Desalniettemin onderzoeken we in dit artikel het verband tussen enerzijds de omvang en samenstelling van huishoudens en anderzijds de omvang en samenstelling van netwerken specifiek voor sterke, nabije relaties met personen met wie belangrijke persoonlijke zaken worden besproken. Zoals gezegd worden relaties met discussiepartners gekarakteriseerd door grote tijdsinvesteringen, emotionele nabijheid en sociale steun en geven een gevoel erbij te horen (Granovetter, 1973). Indien huishoudleden deze kenmerken delen, dan mogen we verwachten dat de rol en functie van huishoudleden juist competitief is met de rol en functie van discussiepartners buiten het huishouden, met als gevolg dat veranderingen in huishoudensamenstelling van grote invloed zijn op sterke relaties buiten het huishouden. Hieronder gaan we gedetailleerder in op de genoemde drie theoretische perspectieven en formuleren vervolgens enkele hypothesen met betrekking tot de relatie tussen huishoudensvormen en kenmerken van het kernnetwerk.

\subsection{Sociale contexten en huishoudensvormen}

Het 'sociale contexten perspectief' op de relatie tussen huishoudensvormen en persoonlijke netwerken is gericht op de invloed van sociale contexten en ontmoetingsmogelijkheden op netwerkkenmerken. Sinds de jaren vijftig van de zoe eeuw hebben verschillende wetenschappers zich beziggehouden met empirisch onderzoek naar de invloed van sociale contexten, zoals de buurt, het werk, de familie, enzovoorts, op persoonlijke relaties en netwerken (zie bijvoorbeeld, Feld, 1981; Fischer, 1977, 1982; Mollenhorst, Völker \& Flap, 2008). De gedeelde aanname is dat persoonlijke relaties ontstaan in contexten die sociale contacten met andere toestaan, danwel stimuleren. 
Een van de bekendste theorieën over de invloed van sociale contexten op persoonlijke relaties is Felds 'focus theory'. Feld (1981) stelde dat het delen van een sociale context met een andere persoon de kans op relatievorming met deze persoon vergroot, maar ook dat het de kans op netwerkoverlap met die persoon vergroot. Dit betekent dat individuen door gedeelde contexten niet alleen in contact worden gebracht met andere individuen, maar ook met nieuwe sociale contexten. Als we deze redenering toepassen op de relatie tussen huishoudensvormen en kenmerken van het (kern-)netwerk, dan kunnen we huishoudens zien als sociale contexten die persoonlijke netwerken mede vormgeven. Huishoudleden kunnen ontmoetingsmogelijkheden en daarmee het ontstaan van relaties met andere individuen positief beïnvloeden, doordat zij het individu in contact brengen met nieuwe sociale contexten. Zo kunnen ouders van voetballende kinderen in contact komen en vervolgens een netwerkrelatie aangaan met andere ouders via de voetbalclub waar hun kind lid van is.

Op basis van deze argumenten mogen we veronderstellen dat grotere huishoudens meer contactmogelijkheden bieden, omdat elk lid van het huishouden het individu in contact kan brengen met nieuwe contexten en personen. De hypothese luidt daarom: er is een positief verband tussen het aantal huishoudleden en het aantal discussiepartners. Naast de invloed op de omvang van het kernnetwerk, kan de aanwezigheid van (verschillende) huishoudleden ook van invloed zijn op verschillende typen relaties in het kernnetwerk buiten het huishouden. Het feit dat individuen toegang krijgen tot verschillende potentiële interactiepartners via hun huishoudleden, suggereert dat er een positief verband is tussen het aantal huishoudleden en het absolute aantal familieleden, niet-familieleden, vrienden en buren in het kernnetwerk.

De aanwezigheid van huishoudleden is mogelijk niet alleen van invloed op het vergroten van ontmoetingsmogelijkheden voor het individu, maar afhankelijk van wie de huishoudleden zijn, ook op de aard van deze ontmoetingsmogelijkheden. Zo zal iemand door een partner met andere sociale contexten in contact gebracht worden dan door een kind. Vanuit structureel perspectief gezien vergroot het samenleven met een partner dan ook de contactmogelijkheden van individuen, aangezien partners geneigd zijn elkaars naaste persoonlijke relaties over te nemen (Kalmijn, 2003). Vanuit dit perspectief luidt de hypothese daarom: er is een positiefverband tussen de aanwezigheid van een partner in het huishouden en het aantal discussiepartners. Bovendien, omdat een partner toegang biedt tot een bestaande set contacten, mogen we verwachten dat er een positiefverband is tussen de aanwezigheid van een partner in het huishouden en het aantal familieleden, 
niet-familieleden, vrienden en buren in het kernnetwerk. ${ }^{1}$ Bevindingen uit eerder onderzoek naar echtparen ondersteunen deze redenering, door te laten zien dat in vergelijking met singles, mensen met een partner gemiddeld een groter persoonlijk netwerk hebben (McPherson, Smith-Lovin \& Brashears, 2006), meer contacten met buren en familieleden onderhouden (Moore 1990) en vaker participeren in sociale activiteiten (Terhell, 2003).

In de literatuur wordt de aanwezigheid van kinderen in het huishouden voornamelijk gezien als een beperking van contactmogelijkheden (zie bijvoorbeeld Munch, McPherson \& Smith-Lovin 1997). Het 'sociale contexten perspectief' biedt echter een alternatieve kijk op de gevolgen van het hebben van kinderen. De aanwezigheid van kinderen in het huishouden brengt door kind-gerelateerde activiteiten, zoals babyzwemmen, voetballende kinderen, of schoolactiviteiten, ouders juist naar nieuwe sociale contexten. Vanuit dit perspectief luidt de hypothese daarom: er is een positiefverband tussen de aanwezigheidvan kinderen in het huishouden en het aantal discussiepartners. Bovendien wordt deze invloed van kinderen op netwerkomvang mogelijk groter naarmate de kinderen ouder worden, aangezien oudere kinderen vaker deelnemen aan activiteiten buitenshuis dan jongere kinderen. We verwachten daarom dat het aantal discussiepartners van individuen toeneemt, naarmate hun kinderen ouder worden. De geboorte en het opgroeien van kinderen worden doorgaans gezien als gebeurtenissen die gedeeld worden met familieleden (Munch e.a., 1997) en grootouders helpen hun kinderen vaak door op hun kinderen te passen (Moore, 1990). Op basis van deze bevindingen verwachten we dat er een positiefverband is tussen de aanwezigheid van kinderen in het huishouden en het aantal familieleden in het kernnetwerk. Bovendien kunnen kinderen, doordat zij participeren in activiteiten buiten het huishouden, hun ouders in contact brengen met mensen in nieuwe sociale contexten. Zo heeft eerder onderzoek laten zien dat de neiging van kinderen om op de speelplaats in de buurt vriendschappen aan te gaan, positief samenhangt met het aantal contacten van hun ouders die zij in lokale contexten ontmoeten (bijv. Campbell \& Lee, 1992). Naar aanleiding hiervan verwachten we dat er een positiefverband is tussen de aanwezigheid van kinderen in het huishouden en het aantal niet-familieleden, vrienden en buren in het kernnetwerk. ${ }^{2}$ We merken ook hierbij op dat deze invloed van kinderen op het aantal specifieke typen netwerkleden mogelijk groter wordt, naarmate de kinderen ouder worden, aangezien oudere kinderen vaker deelnemen aan activiteiten buitenshuis dan jongere kinderen. 


\subsection{Tijdinvesteringen en huishoudensvormen}

Volgens het tijdinversteringperspectief is het verband tussen huishoudensvormen en persoonlijke netwerken een gevolg van beschikbare tijd. In hedendaagse westerse samenleving vervullen individuen vaak verschillende rollen in het dagelijks leven, zoals werknemer in een organisatie, vrijwilliger bij een vereniging en ouder in een gezin. De tijd die iemand tot haar of zijn beschikking heeft, is een beperkte hulpbron die verdeeld moet worden over deze verschillende levensdomeinen (Goode, 1960; Marks, 1970). Deze verschillende domeinen concurreren zogezegd met elkaar voor de beschikbare tijd en energie van individuen, waardoor een zekere spanning kan optreden tussen de verschillende rollen. Vanuit dit perspectief gezien, kunnen we stellen dat de aanwezigheid van huishoudleden een set verplichtingen met zich meebrengt, waaraan een individu een deel van haar of zijn beschikbare tijd zal besteden, met als gevolg dat de beschikbare tijd voor andere domeinen en activiteiten, zoals sociale activiteiten met mensen buiten het huishouden, beperkt wordt. Bovendien zullen meer omvangrijke huishoudens meer tijdsinvestering vragen dan kleinere huishoudens, aangezien een individu haar of zijn tijd dan over meer huishoudleden moet verdelen. De hypothese vanuit dit perspectief luidt daarom: er is een negatiefverband tussen enerzijds het aantal huishoudleden en anderzijds het aantal discussiepartners alsook het aantal van elk type relaties met discussiepartners.

Meer specifiek wordt de aanwezigheid van een partner in het huishouden vaak gezien als een beperkende factor op de tijd die iemand heeft om sociale activiteiten te ondernemen met andere personen (Campbell \& Lee, 1992). Coser (1974) bestempelde het huwelijk daarom als een 'inhalig instituut' dat veel tijdinvestering en constante inzet en toewijding vraagt van de betrokken personen. Empirische bevindingen in voorgaand onderzoek ondersteunen deze aanname door aan te tonen dat gehuwden gemiddeld een kleiner sociaal netwerk hebben dan ongehuwden (Fischer \& Oliker, 1983). Vanuit dit tijdinvesteringsperspectief verwachten we bovendien dat de aanwezigheid van een partner in het huishouden het aantal verschillende typen relaties in het netwerk beperkt, aangezien iemand dan minder tijd over heeft om sociale activiteiten met niet-familieleden, buren en collega's te ondernemen. De hypothese op grond hiervan luidt daarom: er is een negatief verband tussen enerzijds de aanwezigheid van een partner in het huishouden en anderzijds het aantal discussiepartners alsook het aantalvan elk type relaties met discussiepartners.

Naast de aanwezigheid van een partner in het huishouden, kan de aanwezigheid van kinderen in het huishouden ook verschillende verplich- 
tingen met zich meebrengen, waaraan een individu een deel van haar of zijn beschikbare tijd zal besteden. Het opvoeden van en doorbrengen van tijd met kinderen beperkt daarom de beschikbare tijd voor het aangaan en onderhouden van contacten met mensen buiten het huishouden. Empirisch onderzoek naar ouderschap levert ondersteuning voor deze redenering, door aan te tonen dat ouders met kinderen in het huishouden gemiddeld een kleiner sociaal netwerk hebben (Bost e.a., 2002). Op grond hiervan luidt de hypothese: er is een negatief verband tussen enerzijds de aanwezigheid van kinderen in het huishouden en anderzijds het aantal discussiepartners alsook het aantalvan elk type relaties met discussiepartners. We verwachten bovendien dat dit verband sterker is voor mensen met jonge kinderen in het huishouden, aangezien juist jonge kinderen veel tijdinvestering van de ouders vragen in termen van opvoeden, begeleiden en het bieden van fysieke en emotionele zorg.

\subsection{Sociale steun en huishoudensvormen}

Volgens het 'sociale steun perspectief' is iemands behoefte aan sociale steun de drijvende kracht achter het verband tussen huishoudensvormen en persoonlijke netwerken. Sociaal kapitaal wordt breed gezien als een belangrijke hulpbron die ervoor zorgt dat een individu doelen kan bereiken door gebruik te maken van hulpbronnen in haar/zijn sociale omgeving (Flap, 1999). Het is niet verwonderlijk dat de veelzijdige aard van sociaal kapitaal heeft geleid tot een verscheidenheid aan definities, interpretaties en toepassingen van dit concept.

Zo maakte Coleman (1988) bijvoorbeeld een onderscheid tussen sociaal kapitaal binnen en buiten het huishouden, waarbij hij de tijd die huishoudleden met elkaar doorbrengen als belangrijkste bron van sociaal kapitaal binnen het huishouden aanwees. Coleman (1988) stelde dat de fysieke afwezigheid van anderen in het huishouden een structureel gebrek aan sociaal kapitaal vormt, omdat het betreffende individu de toegang ontbeert tot hulpbronnen van huishoudleden. Wagner en Wolf(2001) namen eveneens aan dat huishoudensamenstelling en de behoefte aan sociale steun van mensen buiten het huishouden sterk met elkaar samenhangen. Deze auteurs stelden dat de beschikbaarheid van huishoudleden en de mate waarin zij elkaar sociale steun bieden, bepalend zijn voor iemands behoefte aan sociale steun van buiten het huishouden. Glatzer en Berger-Schmitt (1988), die het huishouden als productiefaciliteit voor welzijn beschouwden, beargumenteerden dat het leveren van sociale steun door het huishouden en de behoefte aan steun afhankelijk zijn van de omvang van het huishouden en de relaties tussen de verschillende leden van het huishouden. 
Op basis van deze argumenten kunnen we aannemen dat de mate waarin iemand behoefte heeft aan sociale steun van buiten het huishouden substantieel beïnvloed wordt door de omvang en samenstelling van het huishouden. Mensen met beperkte mogelijkheden voor uitwisseling van steun binnen het huishouden zullen zich eerder tot mensen buiten het huishouden richten, terwijl zij die meer mogelijkheden voor steun binnen het huishouden hebben minder afhankelijk zijn van externe steunrelaties. De hypothese vanuit dit perspectief luidt daarom: er is een negatiefverband tussen enerzijds het aantal huishoudleden en anderzijds het aantal discussiepartners alsook het aantal van elk type relaties met discussiepartners.

Eerder onderzoek suggereert bovendien dat iemands rol in relatie tot haar/zijn huishoudleden een bepalende factor is voor de vraag naar sociale steun: familierelaties binnen het huishouden, zoals die tussen partners, zijn een waardevolle bron van sociale steun, aangezien partners in staat zijn op verscheidene manieren emotionele en instrumentele steun te bieden (Dykstra, 1993; Wellman \& Wortley, 1990; Song, 2012). Onze hypothese luidt daarom: er is een negatiefverband tussen enerzijds de aanwezigheid van een partner in het huishouden en anderzijds het aantal discussiepartners alsook het aantal van elk type relaties met discussiepartners. De aanwezigheid van een partner heeft mogelijk vooral consequenties voor (sterke) instrumentele banden met bijvoorbeeld buren en collega's, aangezien buren en collega's vaak slechts beperkte sociale steun geven, die ook goed gegeven kan worden door een partner (Campbell \& Lee, 1992; Wellman \& Wortley, 1990).

Het verband tussen de aanwezigheid van kinderen in het huishouden en kenmerken van persoonlijke netwerken is anders. Het opvoeden van kinderen wordt doorgaans beschouwd als een factor die de behoefte aan sociale steun van mensen buiten het huishouden vergroot, aangezien kleine kinderen constante zorg en aandacht nodig hebben. Hulp bij het zorgen voor en passen op kinderen wordt veelvuldig verleend door nabije familie, vrienden en buren. Op grond hiervan luidt de hypothese: er is een positief verband tussen enerzijds de aanwezigheid van kinderen in het huishouden en anderzijds het aantal discussiepartners alsook het aantal familieleden, niet-familieleden, vrienden en buren in het kernnetwerk. We verwachten hierbij dat het positieve verband tussen de aanwezigheid van kinderen en de aantallen van de diverse typen relaties in het kernnetwerk met name gevonden wordt, indien er jonge kinderen in het huishouden aanwezig zijn en zwakker wordt naarmate kinderen ouderen worden en zelf steun kunnen geven aan andere huishoudleden. ${ }^{2}$ Tabel 1 geeft een overzicht van onze hypotheses en geeft aan voor welke aspecten van huishoudensamenstelling 
de drie perspectieven tot dezelfde voorspellingen leiden en waar de drie perspectieven uiteenlopende of tegengestelde voorspellingen opleveren.

Tabel 1 Hypothesen

\begin{tabular}{|c|c|c|c|c|c|c|}
\hline \multirow[b]{2}{*}{ Perspectieven } & \multicolumn{6}{|c|}{ Netwerkomvang en -samenstelling } \\
\hline & $\begin{array}{l}\text { Netwerk- } \\
\text { omvang }\end{array}$ & $\begin{array}{l}\text { \# Familie- } \\
\text { leden }\end{array}$ & $\begin{array}{l}\text { \# Niet- } \\
\text { familieleden }\end{array}$ & \# Vrienden & \# Buren & \#Collega's \\
\hline \multicolumn{7}{|l|}{ Sociale contexten perspectief } \\
\hline Aantal huishoudleden & + & + & + & + & + & $?$ \\
\hline Aanwezigheid van partner & + & + & + & + & + & $?$ \\
\hline Aanwezigheid van kinderen & + & + & + & + & + & $?$ \\
\hline \multicolumn{7}{|l|}{ Tijdinvesteringsperspectief } \\
\hline Aantal huishoudleden & - & - & - & - & - & - \\
\hline Aanwezigheid van partner & - & - & - & - & - & - \\
\hline Aanwezigheid van kinderen & - & - & - & - & - & - \\
\hline \multicolumn{7}{|l|}{ Sociale steun perspectief } \\
\hline Aantal huishoudleden & - & - & - & - & - & - \\
\hline Aanwezigheid van partner & - & - & - & - & - & - \\
\hline Aanwezigheid van kinderen & + & + & + & + & + & $?$ \\
\hline
\end{tabular}

$+=$ positief verband; $-=$ negatief verband; $?=$ geen eenduidige hypothese

\section{Data en methoden}

\subsection{Data}

We toetsen onze hypothesen aan de hand van cross-sectionele data die zijn voortgekomen uit de 'Survey on the Social Networks of the Dutch' (SSND; Völker e.a., 2008). Deze dataset bevat gedetailleerde informatie over zowel de samenstelling van het huishouden als over het persoonlijk netwerk van de respondenten. Om deze gegevens te verzamelen werd in 1999/200o een gestratificeerde aselecte steekproef getrokken van veertig van de bij benadering vijfhonderd Nederlandse gemeenten (verdeeld over de verschillende provincies en regio's), waarbij rekening werd gehouden met de mate van stedelijkheid en het aantal inwoners van deze gemeenten. In elke gemeente werden aselect vier buurten geselecteerd aan de hand van het postcodesysteem. Vervolgens werden per buurt 25 adressen geselecteerd en werd op acht van deze adressen de bewoner geïnterviewd die tussen de 18 en 65 jaar oud was en het eerst jarig zou zijn. Met een responspercentage van $40 \%$ leverde dit informatie op van 1007 respondenten in 161 verschillende Nederlandse buurten. 
In 2007 achterhaalden we de adressen van 863 van de oorspronkelijke respondenten. $70 \%$ van hen was bereid opnieuw deel te nemen aan dit onderzoek. Dit resulteerde in een panel dataverzameling met informatie van 604 personen in Nederland in de leeftijd van 26 tot 72 jaar in 2007 (zie Völker e.a., 2008). In 2007/2008 werden onderzoekbuurten waar respondenten - om welke redenen dan ook - waren uitgevallen voor dit onderzoek, weer aangevuld met 394 nieuwe respondenten.

In deze studie gebruiken we de informatie van alle respondenten die in 2007/2008 werden geïnterviewd (oftwel, de panel-respondenten en de toegevoegde respondenten). Deze dataset bevat gegevens van in totaal 998 respondenten in de leeftijd van 18 tot 89 jaar. Uit een vergelijking van onze gegevens met nationale statistieken over een aantal sociaaldemografische kenmerken is gebleken dat mannen, gehuwden, ouderen en hoger opgeleiden iets zijn oververtegenwoordigd. Bovendien werden bij de initiële steekproeftrekking disproportioneel meer mensen met een betaalde baan geselecteerd. Waar mogelijk controleren we in onze analyses voor deze kenmerken van de respondent.

\subsection{Metingen}

Tijdens de interviews werden de persoonlijke netwerken van de respondenten in kaart gebracht aan de hand van dertien zogenoemde 'naamgenererende vragen' over een verscheidenheid aan typen relaties, sociale interacties en sociale contexten. Een van deze naamgenererende vragen luidt: 'Met wie heeft u gedurende het afgelopen half jaar belangrijke persoonlijke zaken besproken?'. Als antwoord op deze vraag mochten respondenten namen (of bijnamen of initialen) noemen van personen die zij al bij voorafgaande naamgenererende vragen hadden genoemd en deze aanvullen met maximaal vijf nog niet eerder genoemde namen. ${ }^{3}$ In netwerkstudies is deze naamgenerator veelvuldig gebruikt om het zogenoemde 'core discussion network' in kaart te brengen (cf. Burt, 1984; Bailey \& Marsden, 1999; Marsden, 1987; McPherson e.a., 2006). Zoals eerder vermeld noemen we deze personen in dit artikel 'discussiepartners', die samen iemands 'kernnetwerk' vormen.

Na de namen van de netwerkleden te hebben verzameld, werden verschillende 'naaminterpreterende vragen' gesteld om informatie te verkrijgen over de netwerkleden en de relatie tussen de respondent en de netwerkleden. Zo werd gevraagd naar verschillende sociaaldemografische kenmerken van de netwerkleden (zoals leeftijd, geslacht, opleidingsniveau, nationaliteit, etc.), alsook naar de sterkte en het type relatie tot de respondent (zoals partner, kind, ouder, vriend, collega, buur, etc.). Achttien respondenten hebben de 
netwerkvragen niet beantwoord in de SSND. Aangezien deze informatie cruciaal is voor onze studie, laten we deze personen bij de analyses buiten beschouwing.

\subsection{Afhankelijke variabelen}

In deze studie richten we ons op twee kernparameters van het netwerk, namelijk omvang en samenstelling. Omvang van het kernnetwerk is het aantal discussiepartners dat niet tot het huishouden van de respondent behoort. Als antwoord op de zojuist beschreven naamgenerende vraag konden respondenten zowel discussiepartners binnen als buiten hun huishouden noemen. Omdat in deze studie echter het verband tussen enerzijds de omvang en samenstelling van het huishouden en anderzijds de kenmerken van het kernnetwerk centraal staat, laten we voor de bepaling van de omvang en samenstelling van het kernnetwerk de huishoudleden buiten beschouwing. We merken nogmaals op dat waar we in deze studie spreken over discussiepartners en kernnetwerken, we niet telkens benoemen dat het daarbij gaat om discussiepartners die niet tot het huishouden van de respondent behoren.

De samenstelling van het kernnetwerk is gebaseerd op de vraag op welke manier de respondent met de betreffende persoon verbonden was. Deze vraag luidde: 'Wat is de relatie tussen u en [...]?'. Als antwoord op deze vraag konden respondenten kiezen uit de volgende achttien verschillende rolrelaties tot personen buiten het huishouden: mijn partner, mijn vader/ moeder, mijn kind, een schoonouder, een broer/zus, een ander familielid, vriend, baas, directe collega, andere collega, ex-collega, iemand die voor mij werkt, iemand uit de buurt waar ik woon, mijn naaste buur, ex-buur, iemand die lid is van dezelfde club of vereniging als ik, een kennis, of 'iets anders, namelijk...'. Naar voorbeeld van Moore (1990) hebben we de eerste zes rolrelaties geclassificeerd als 'familie' en de ander twaalf als 'niet-familierelaties'. De rollen van baas, directe collega, andere collega, ex-collega en iemand die voor u werkt hebben we samengenomen onder de noemer 'collega' en de categorieën directe buur, ex-buur en iemand uit de buurt hebben we samengebracht tot de categorie 'buur'. Relaties met ex-buren en ex-collega's rekenen we tot de categorieën buren en collega's, aangezien deze relaties sterk gerelateerd zijn aan de buurt en de organisatie waar de respondent werkt(e). Ten slotte hebben we de kennissen, leden van dezelfde organisatie/vereniging, en de netwerkleden die niet tot een van de gedefinieerde categorieën gerekend werden, samengenomen in de restcategorie 'overige netwerkleden'. 
In drie gevallen had de respondent de rolrelatie tot een bepaalde discussiepartner niet genoemd. Omdat we hierdoor niet konden vaststellen of het hierbij om iemand van binnen het huishouden ging of om een discussiepartner buiten het huishouden, hebben we deze netwerkleden buiten beschouwing gelaten. Indien de respondent meerdere rolrelaties noemde per discussiepartner, hebben we iedere aangegeven rol meegenomen in onze analyses ten aanzien van de verschillende typen relaties. Bijvoorbeeld, als een respondent aangaf dat een discussiepartner niet alleen zijn buurman is maar ook zijn vriend, dan werd deze discussiepartner meegenomen in de analyse van het aantal buren in het kernnetwerk, alsook in de analyse van het aantal vrienden in het kernnetwerk. Indien twee of meer rolrelaties als gevolg van onze hercategorisering tot dezelfde categorie behoren (bijvoorbeeld baas en directe collega), dan werd de betreffende discussiepartner slechts één keer meegenomen in de analyse. En ten overvloede, bij de analyse van de omvang van het kernnetwerk telt iedere discussiepartner slechts één keer mee, ongeacht het aantal genoemde rolrelaties.

Discussiepartners die door de respondent als huishoudlid werden aangemerkt, werden alleen tot het huishouden gerekend en niet tot het kernnetwerk, ongeacht of deze persoon ook werd aangemerkt als niet-familielid. Op basis van deze classificaties construeerden we zes indicatoren voor rollen in netwerken, die samen de samenstelling van het netwerk weergeven: het aantal familieleden, het aantal niet-familieleden, het aantal vrienden, het aantal collega's, het aantal buren, en het aantal overige netwerkleden. Laatstgenoemde categorie, het aantal overige netwerkleden, wordt niet nader geanalyseerd, aangezien dit een restcategorie betreft waarvan de betekenis niet eenduidig is (Moore, 1990).

\subsection{Onafhankelijke variabelen}

Als onafhankelijke variabelen in onze analyses gebruiken we de volgende metingen voor kenmerken van het huishouden van de respondent: omvang van het huishouden, de aanwezigheid van een partner in het huishouden, en de aanwezigheid van één of meerdere kinderen in het huishouden. Aantal huishoudleden is een discrete variabele die het aantal personen aangeeft waarmee de respondent een huishouden deelt. In de analyses laten we een dertigtal cases buiten beschouwing, omdat we van de betreffende respondenten geen complete informatie over het huishouden hebben of omdat de respondent met personen een huishouden deelde die geen partner of kind van haar of hem zijn. De aanwezigheid van een partner in het huishouden is een dichotome variabele (o = geen partner in het huishouden; 1 = wel een partner in het huishouden). De aanwezigheid van kinderen in het 
huishou den betreft eveneens een dichotome variabele $(0=$ geen kinderen in het huishouden; 1 = één of meerdere kinderen in het huishouden). En voor de analyses waarin we in detail kijken naar de aanwezigheid van kinderen in specifieke leeftijdscategorieën gebruiken we een drietal dichotome variabelen: kinderen van o tot en met 4 jaar in het huishouden; kinderen van 5 tot en met 12 jaar in het huishouden; kinderen ouder dan 12 jaar in het huishouden (waarbij geldt: 0 = niet aanwezig; 1 = wel één of meerdere aanwezig).

\subsection{Controlevariabelen}

In de multivariate analyses controleren we voor een aantal socio-demografische kenmerken van de respondent, omdat bepaalde categorieën licht oververtegenwoordigd zijn in onze dataverzameling en/of omdat we op basis van eerder onderzoek verwachten dat deze kenmerken samenhangen met de omvang en samenstelling van persoonlijke netwerken (zie bijvoorbeeld McPherson et al., 2006). Leeftijd telt het aantal levensjaren van de respondent (missende waarden werden vervangen door het gemiddelde van de steekproef). Als indicator voor het geslacht van de respondent gebruiken we de dichotome variabele $\operatorname{man}(\mathbf{0}=$ vrouw; $1=$ man). Voor het opleidingsniveau gebruiken we een variabele die de hoogst afgeronde opleiding van de respondent aangeeft, waarbij we de volgende vier categorieën hanteren: geen opleiding of basisonderwijs; lager beroepsonderwijs of lager of middelbaar voortgezet onderwijs; hoger voortgezet onderwijs of middelbaar beroepsonderwijs; hoger beroepsonderwijs of universiteit. Als algemene indicatie voor de nationaliteit van de respondent gebruiken we de dichotome variabele geboren in Nederland ( $0=$ nee; $1=\mathrm{ja}$ ). Om het hebben van een betaalde baan en de tijdinvestering die daarmee gemoeid gaat te indiceren, gebruiken we de variabele aantal werkuren per week. Voor de elf respondenten die wel aangaven een betaalde baan te hebben maar geen aantal werkuren hebben genoemd, hebben we het gemiddelde van de andere werkenden in de steekproef genomen. In tabel 2 geven we een overzicht van beschrijvende statistieken met betrekking tot alle beschreven variabelen. 
de significantie van parameters (Long, 2004). Negatief binomiale regressie is in staat rekening te houden met deze specifieke kenmerken van deze gegevens en vormt daarmee een geschikte methode voor ons onderzoek. ${ }^{4}$ Door het toevoegen van een spreidingsparameter aan het mathematische model houdt negatief binomiale regressie rekening met onzekerheden die niet zijn toegestaan bij Poissonmodellen (Long, 1997).

In de tabellen 3 a en 3 b presenteren we de resultaten van de multivariate negatief binomiale regressieanalyses. We beginnen met een model waarin naast de controle variabelen ook de variabele voor de omvang van het huishouden is opgenomen (model 1). Vervolgens vervangen we de variabele voor de omvang van het huishouden door twee specifiekere indicatoren voor huishoudensamenstelling: de aanwezigheid van een partner in het huishouden en de aanwezigheid van een of meerdere kinderen in het huishouden (model 2). Om rekening te houden met de leeftijd van de aanwezige kinderen in het huishouden, vervangen we ten slotte de algemene variabele voor de aanwezigheid van kinderen door de drie variabelen die de aanwezigheid van kinderen in verschillende leeftijdscategorieën aangeven (model 3).

\section{Resultaten}

In de tabellen $3^{a}$ en $3^{b}$ presenteren we de resultaten van de verschillende multivariate negatief binomiale regressieanalyses van de omvang en samenstelling van de kernnetwerken. De a-versie van elk model toont het verband tussen de omvang van het huishouden en de afhankelijke variabele, controlerend voor een aantal socio-demografische kenmerken van de respondent. Zo zien we dat in vergelijking met singles, personen met een groter huishouden gemiddeld een wat kleiner kernnetwerk hebben. Een extra huishoudlid hangt samen met een afname van 0,093 van de natuurlijke logaritme van het aantal mensen van buiten hun huishouden waarmee ze belangrijke persoonlijke zaken bespreken. Procentueel uitgedrukt zorgt ieder extra huishoudlid voor een afname van het kernnetwerk met 9,6\%. ${ }^{5}$ Wanneer we kijken naar de opdeling familie versus niet-familie, dan zien we dat de omvang van het huishouden negatief samenhangt met zowel het aantal familieleden als met het aantal niet-familieleden in het kernnetwerk. Bij ieder extra huishoudlid neemt de natuurlijke logaritme van het aantal familieleden in het netwerk af met 0,131 (oftewel, een afname van $12,3 \%)$. Het negatieve verband tussen huishoudensomvang en het aantal niet-familieleden in het kernnetwerk wordt bepaald door een lager aantal vrienden onder de discussiepartners van mensen met een groter huishouden 


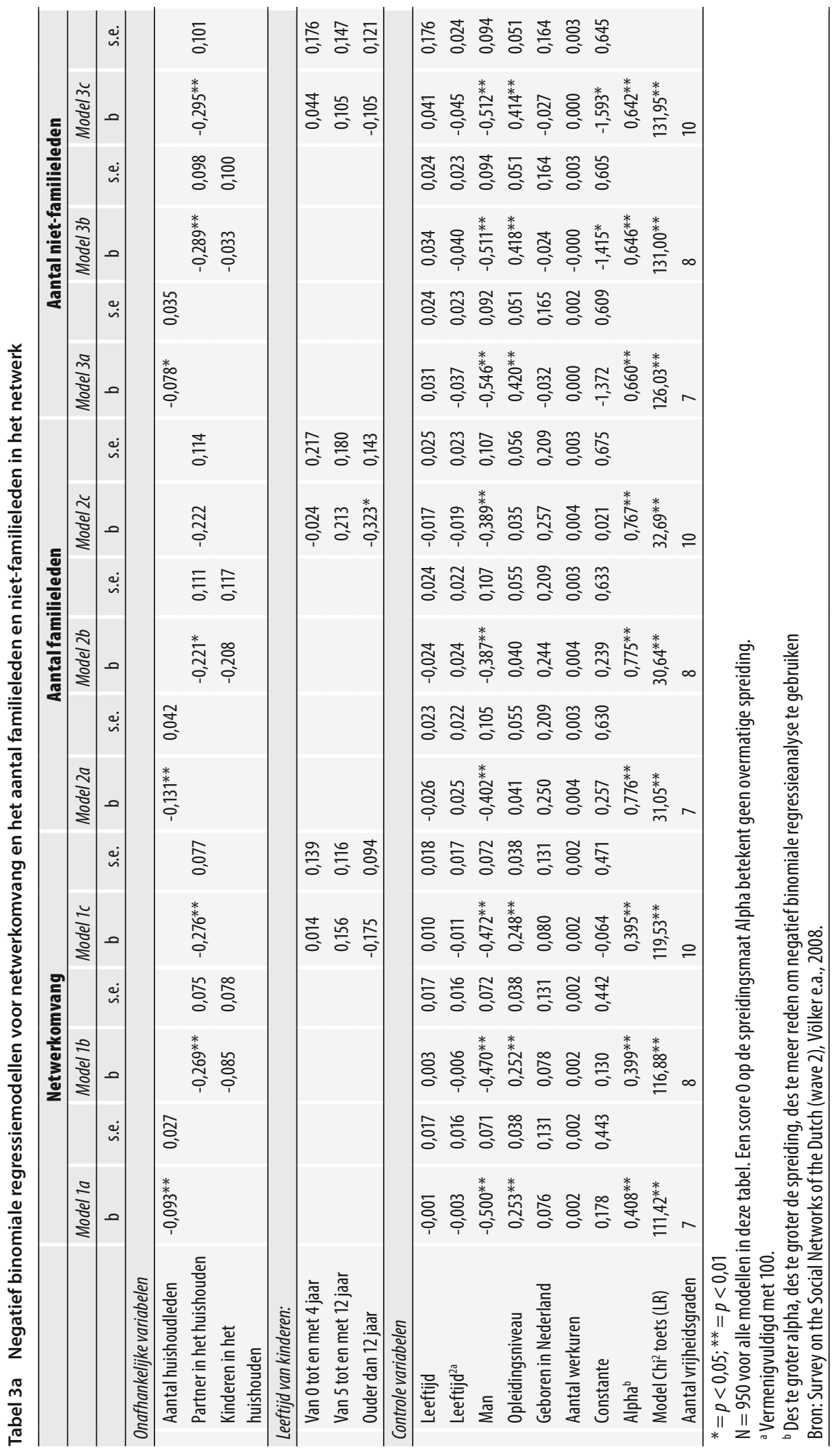




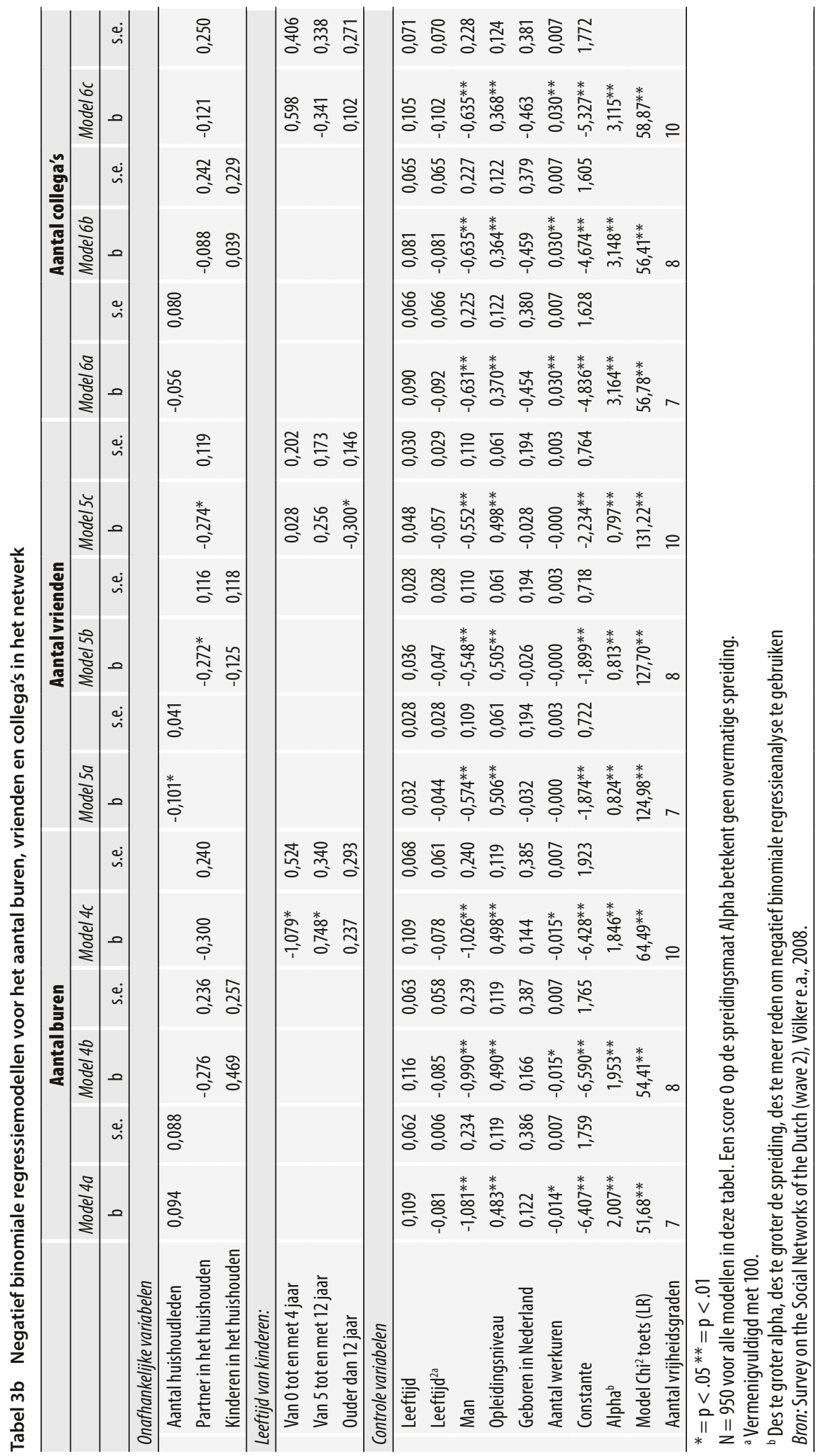


(zie tabel $3 \mathrm{~b}$, middelste kolom). Tegen onze verwachting in vinden we geen significant verband tussen huishoudensomvang en het aantal collega's en buren in het kernnetwerk.

In de b-versie van elk model presenteren we de resultaten van het verband tussen de relatie tot huishoudleden (partner of kind) en de omvang en samenstelling van het kernnetwerk. En in de c-versie van elk model houden we bovendien rekening met de leeftijd van de aanwezige kinderen in het huishouden. Deze modellen laten een duidelijk negatief verband zien tussen de aanwezigheid van een partner in het huishouden en de omvang en samenstelling van het kernnetwerk buiten het huishouden. In model $1 \mathrm{~b}$ zien we bijvoorbeeld dat in vergelijking met singles, personen die samenleven met een partner een $23,6 \%$ kleiner kernnetwerk hebben $(b=-0,269 ; p<0,01)$. Dit negatieve verband tussen het samenleven met een partner en het aantal discussiepartners buiten het huishouden geldt voor zowel het aantal familieleden als het aantal niet-familieleden in het kernnetwerk. Zo hebben mensen die met een partner samenleven gemiddeld $25,6 \%$ minder niet-familieleden in hun kernnetwerk (model $3 b ; b=-0,289$; $p<0,001)$ in vergelijking tot singles, hetgeen een resultaat is van een kleiner aantal vrienden in hun kernnetwerk (model 5 b). In de c-versies van de modellen zien we dat het verband tussen de aanwezigheid van een partner in het huishouden en de omvang en samenstelling van het kernnetwerk in de meeste gevallen significant en onveranderd blijft indien we rekening houden met de leeftijd van de aanwezige kinderen in het huishouden. Alleen het negatieve verband tussen de aanwezigheid van een partner en het aantal familieleden onder de discussiepartners is niet langer statistisch significant, indien we een grenswaarde van $5 \%$ overschrijdingskans hanteren (model 2c; $b=-0,222 ; p=0,052)$. Ook hier vinden we geen significant verband tussen de aanwezigheid van een partner in het huishouden en het aantal collega's en buren in het kernnetwerk.

Wat betreft de aanwezigheid van kinderen in het huishouden laten de b-versies van de modellen zien dat we geen significante samenhang vinden tussen louter de aanwezigheid van kinderen in het huishouden en netwerkomvang en -samenstelling. De c-versies van de modellen laten echter zien dat de aanwezigheid van kinderen in een bepaalde leeftijdscategorie wel samenhangt met de samenstelling van het kernnetwerk. We zien bijvoorbeeld een negatief verband tussen de aanwezigheid van kinderen tussen o en 4 jaar en het aantal buren in het kernnetwerk (model 4c; $b=$ $-1,079 ; p<0,05)$. De aanwezigheid van kinderen tussen o en 4 jaar verkleint het percentage buren in het netwerk met $66 \%$, terwijl de aanwezigheid van kinderen tussen 5 en 12 jaar juist samengaat met meer buren in het 
kernnetwerk (model 4c; $b=0,748 ; p<0,05$ ). Daarnaast zien we een negatief verband tussen de aanwezigheid van kinderen ouder dan 12 jaar in het huishouden en zowel het aantal familieleden als het aantal vrienden in het kernnetwerk. De aanwezigheid van één of meerdere kinderen ouder dan 12 jaar in het huishouden hangt samen met $25,9 \%$ minder vrienden (model $5 \mathrm{c}$; $b=-0,300 ; p<0,05$ ) en 27,6\% minder familieleden in het kernnetwerk (model 2c; $b=-0,323 ; p<0,05)$. Tegen onze verwachtingen in laten deze resultaten dus zien dat de aanwezigheid van kinderen in het huishouden in het algemeen dus slechts beperkte invloed heeft op de omvang en samenstelling van het kernnetwerk.

Wat de controlevariabelen betreft zien we in de verschillende modellen van de tabellen $3^{a}$ en $3^{b}$ geen significant verband tussen de leeftijd van de respondent en de omvang en samenstelling van het kernnetwerk. Voor het geslacht van de respondent zien we wel significante resultaten: mannen hebben gemiddeld een kleiner aantal discussiepartners en dat gaat specifiek om zowel minder familieleden als minder niet-familieleden. Opleidingsniveau hangt positief samen met het aantal discussiepartners, maar dat betreft alleen het aantal niet-familieleden. En zoals verwacht zien we dat het aantal uren betaalde arbeid per week samenhangt met een substantieel groter aantal collega's en een kleiner aantal buren in het kernnetwerk.

\section{Conclusie en discussie}

Het hoofddoel van deze studie was te onderzoeken hoe huishoudensvormen en kenmerken van persoonlijke netwerken met elkaar samenhangen. Om deze vraag te beantwoorden maakten we gebruik van een rijke dataverzameling onder bijna duizend respondenten die representatief zijn voor de Nederlandse bevolking van 18 jaar en ouder. We hebben gevonden dat in vergelijking tot mensen die met meerdere mensen een huishouden vormen, singles gemiddeld met een groter aantal mensen buiten hun huishouden belangrijke persoonlijke zaken bespreken en dat dit met name meer familieleden en vrienden betreft. Deze resultaten zijn in tegenspraak met onze hypotheses die we baseerden op het sociale contexten perspectief. Volgens dit perspectief zou de aanwezigheid van anderen in het huishouden er juist voor zorgen dat iemand in meer verschillende sociale contexten terechtkomt, waardoor de contactmogelijkheden met mensen buiten het huishouden toenemen, wat tot een groter en meer divers (kern-)netwerk zou leiden. Zowel het tijdinvesteringsperspectief als het sociale steun 
perspectief voorspellen dat een groter aantal huishoudleden samengaat met een kleiner en minder divers samengesteld (kern-)netwerk. Onze bevindingen zijn in lijn met het argument dat mensen die alleen wonen meer tijd beschikbaar hebben om sociale activiteiten - zoals het praten over belangrijke persoonlijke zaken - te ondernemen met vrienden, familieleden en niet-familieleden buiten het huishouden. Dit met als gevolg dat singles een groter en meer divers samengesteld kernnetwerk hebben dan personen die met meerdere mensen een huishouden vormen. Het is echter ook mogelijk dat personen met een kleiner huishouden zich voor steun eerder tot vrienden, niet-familieleden en familieleden buiten het huishouden richten, omdat zij binnen het huishouden onvoldoende steun (kunnen) ontvangen (Wagner \& Wolf, 2001).

Onze analyses lieten ook een duidelijk verband zien tussen de samenstelling van het huishouden en de omvang en samenstelling van het kernnetwerk. Personen die samenleven met een partner hebben gemiddeld een kleiner kernnetwerk, met name vanwege een kleiner aantal familieleden en vrienden waarmee ze belangrijke persoonlijke zaken bespreken. Ook deze bevindingen zijn in tegenspraak met het sociale contexten perspectief. In plaats daarvan zijn deze bevindingen wel in lijn met beide andere perspectieven: de aanwezigheid van de partner betekent een sterke aanslag op iemands tijd waardoor er minder tijd overblijft voor sociale activiteiten met anderen buiten het huishouden en/of dat iemand minder steun nodig heeft van mensen buiten het huishouden (Campbell \& Lee, 1992; Song, 2012).

Wat kinderen in het huishouden betreft, zagen we weliswaar geen verband tussen netwerkomvang en -samenstelling en louter de aanwezigheid van kinderen, maar zagen we wel netwerkverschillen indien we specifieker keken naar de leeftijd van deze kinderen in het huishouden. Terwijl mensen met kleine kinderen tot vier jaar in het huishouden minder buren in het kernnetwerk hebben, geven mensen met kinderen tussen 5 en 12 jaar oud juist aan met meer buren hun belangrijke persoonlijke zaken te bespreken. Een mogelijke verklaring hiervoor is dat de zorg voor kinderen tot 4 jaar een dermate grote tijdinvestering vraagt dat de betreffende ouders minder tijd beschikbaar hebben om te socializen met buren, waardoor zij ook minder vaak als discussiepartner worden genoemd. Kinderen in de leeftijd van 5 tot 12 jaar brengen hun ouders juist in contact met buren, aangezien kinderen in deze leeftijdscategorie vaak omgaan en spelen met kinderen uit de buurt, op het speelveld of op straat. Deze laatstgenoemde bevinding is in overeenstemming met het sociale contexten perspectief. Tevens vonden we een negatief verband tussen de aanwezigheid van kinderen boven de 12 jaar in het huishouden en het aantal vrienden en familieleden buiten het 
huishouden in het kernnetwerk. Deze samenhang kunnen we het beste verklaren aan de hand van het sociale steun perspectief. Kinderen in deze leeftijdscategorie kunnen zelf een belangrijke bron van sociale steun en gezelligheid zijn voor hun ouders, waarmee zij de behoefte van deze ouders verminderen om veel nabije sociale contacten buiten het huishouden te onderhouden.

Wanneer we onze bevindingen beschouwen in het licht van waarneembare actuele trends wat betreft huishoudensvormen, dan zien we niet dat singles sociaal minder goed geïntegreerd zijn dan personen die met meerdere personen een huishouden vormen. Juist degenen met een groter huishouden noemen minder discussiepartners buiten het huishouden. We vinden daarmee geen ondersteuning voor het vaak gebruikte argument dat partnerrelaties en het huwelijk de basis vormen voor sociale steun en sociale integratie in de samenleving (Waite \& Gallagher, 200o).

We zien uit naar toekomstig onderzoek waarin aandacht wordt besteed aan een aantal punten die na deze studie nog niet duidelijk zijn. Het eerste punt is dat wij niet in staat waren om de verschillende theoretische perspectieven te bevestigen danwel te weerleggen, vanwege het feit dat ons databestand niet de juiste directe meetinstrumenten bevat met betrekking tot sociale contexten, tijdinvesteringen en sociale steun. Mogelijke meetinstrumenten om dergelijke directe toetsingen mogelijk te maken, zijn bijvoorbeeld de hoeveelheid tijd die iemand doorbrengt met ieder van haar of zijn huishoudleden, de hoeveelheid sociale steun die zij of hij van hen ontvangt en de sociale contexten waarin de respondenten, de huishoudleden en de netwerkleden elkaar ontmoeten. Wij stellen dat het gebruik van dergelijke directe toetsingen van het sociale contexten perspectief, het tijdinvesteringsperspectief en het sociale steun perspectief het voornaamste aandachtspunt van toekomstig onderzoek op dit vlak dient te zijn. Ten tweede kunnen longitudinale gegevens hulp bieden om de causaliteitsvraag te beantwoorden. Tot zover baseren we onze assumpties ten aanzien van causaliteit tussen huishoudensvorm en kenmerken van sociale netwerken op theoretische argumenten. Aan de hand van longitudinale data kan mogelijk empirische ondersteuning gevonden worden voor deze argumenten.

Ondanks deze beperkingen van onze studie laten we wel zien dat netwerkpatronen afhankelijk zijn van huishoudensvormen. Deze bevinding vraagt om meer onderzoek waarin inzichten uit sociologisch onderzoek naar huishoudens, de levensloop en sociale netwerken worden gecombineerd. 


\section{Noten}

1. Vanuit dit theoretisch perspectief verwachten we geen significant verband tussen de aanwezigheid van een partner in het huishouden en het aantal collega's in het kernnetwerk.

2. Vanuit dit theoretisch perspectief verwachten we geen significant verband tussen de aanwezigheid van kinderen in het huishouden en het aantal collega's in het kernnetwerk.

3. Slechts $1,44 \%$ van de respondenten maakte gebruik van de mogelijkheid om als antwoord op deze vraag vijf nieuwe (d.w.z. niet bij eerder gestelde naamgenererende vragen genoemde) namen te noemen. Dit betekent dat het gestelde maximum maar zeer beperkt tot beknotting van het aantal discussiepartners leidt.

4. Parallelle OLS-regressieanalyses voor alle gebruikte netwerkkenmerken leiden tot dezelfde inhoudelijke conclusies.

5. De procentuele verandering van het verwachte aantal (de uitkomst op de afhankelijke variabele) bij een verandering van 1 unit van de onafhankelijke variabele kan berekend worden aan de hand van de formule: $100 \times\left[\exp \left(\beta_{k} \times \delta\right)-1\right]($ zie Long \& Freese, 2004).

\section{Literatuur}

Alwin, D.F., Converse, P.E. \& Martin, S. (1985). Living arrangements and social integration. Journal of Marriage and the Family, 47, 319-334.

Bailey, S. \& Marsden, P.V. (1999). Interpretation and interview context: Examining the General Social Survey name generator using cognitive methods. Social Networks, 21, 287-309.

Bost, K., Cox, M.J., Burchinal, M.R. \& Payne, C. (2002). Structural and supportive changes in couples' family and friendship networks across the transition to parenthood. Journal of Marriage and the Family, 64, 517-531.

Burt, R.S. (1984). Network Items and the General Social Survey. Social Networks, 6, 293-339.

Campbell, K.E. \& Lee, B.A. (1992). Sources of personal neighbor networks: Social integration, need, or time? Social Forces, 70, 1077-1100.

Coleman, J.S. (1988). Social capital and the creation of human capital. American Journal of Sociology, 94 (Supplement): S95-S120.

Coser, L.A. (1974). Greedy institutions. Free Press, New York.

Dykstra, P. (1993). The differential availability of relationships and the provision and effectiveness of support to older adults. Journal of Social and Personal Relationships, 10, 355-370.

Feld, S.L. (1981). The Focused Organization of Social Ties. American Journal of Sociology, 86, 1015-1035.

Fischer, C.S. (1977). Perspectives on community and personal relations. In: Fischer, C.S. (Ed.) Networks and places: Social relations in the urban setting. Free Press, New York.

Fischer, C.S. (1982). To dwell among friends: Personal networks in town and city. University of Chicago Press, Chicago.

Fischer, C.S. \& Oliker, S.J. (1983). A research note on friendship, gender and the life cycle. Social Forces, 62, 124-133.

Flap, H. (1999). Creation and returns of social capital. A new research program. La Revue Tocqueville, 20, 1-22.

Glatzer, W. \& Berger-Schmitt, R. (1988). Household composition, social networks and household production in Germany." In: Pahl, R.E. (Ed.) On Work. Historical, Comparative and Theoretical Approaches. Basil Blackwell, Oxford, pp. 513-526.

Goode, W.J. (1960). A theory of role strain. American Sociological Review, 25, 483-496. 
Graaf, A. de (2011). Gezinnen in cijfers. In: Bucx, F. (Ed.) Gezinsrapport 2011. Een portret van de gezinnen in Nederland. Den Haag, SCP, pp. 35-61.

Granovetter, M.S. (1973). The strength of weak ties. American Journal of Sociology, 78, 1360-1380.

Hart, J. de, Knol, F., Maas-de Waal, C., Roes, T. (2002).Zekere banden. Sociale cohesie, leefbaarheid en veiligheid. Sociaal en Cultureel Planbureau, Den Haag.

Kalmijn, M. (2003). Shared friendship networks and the life-course: An analysis of survey data on married and cohabiting couples. Social Networks, 25, 231-249.

Long, J.S. \& Freese, J. (2004). Regression models for categorical variables using Stata. Stata Press, College Station.

Long, J.S. (1997). Regression models for categorical and limited dependent variables. Sage Publications, Thousand Oaks.

Marks, S. (1970). Multiple roles and role stains: Some notes on human energy, time and commitment. American Sociological Review, 42, 921-936.

Marsden, P.V. (1987). Core discussion networks of Americans. American Sociological Review, 52, 122-131.

McPherson, J.M., Smith-Lovin, L. \& Brashears, M.E. (2006). Social isolation in America: Changes in core discussion networks over two decades. American Sociological Review, 71, 353-375.

Mollenhorst, G., Völker, B. \& Flap, H. (2008). Social contexts and personal relationships: The effect of meeting opportunities on similarity for personal relationships of different strength. Social Networks, 3o, 6o-68.

Moore, G. (1990). Structural determinants of men's and women's personal networks. American Sociological Review, 55, 726-735.

Munch, A., McPherson, J.M. \& Smith-Lovin, L. (1997). Gender, children, and social contact: The effect of childrearing for men and women. American Sociological Review, 62, 509-520.

Rijken, A.J. \& Liefbroer, A.C. (2011). Opvattingen over gezinsvorming. In: Bucx, F. (Ed.), Gezinsrapport 2011. Een portret van het gezinsleven in Nederland, Den Haag: SCP, pp. 62-77.

Song, L. (2012). Raising network resources while raising children? Access to social capital by parenthood status, gender, and marital status. Social Networks, 34, 241-252.

Terhell, E.L. (2003). Changes in personal networks after divorce. Thela Thesis, Amsterdam.

Völker, B., Flap, H. \& Mollenhorst, G. (2008). The survey on the social networks of the Dutch, second wave $\left(S S N D_{2}\right)$. Data and codebook. University Utrecht / ICS.

Wagner, M. \& Wolf, C. (2001). Altern, Familie und Soziales Netzwerk. Zeitschrift für Erziehungswissenschaften, 4, 529-554.

Waite, L.J. \& Gallagher, M. (2000). The case for marriage: Why married people are happier, healthier, and better off financially. Doubleday, New York.

Wellman, B. \& Wortley, S. (1990). Different strokes from different folks: Community ties and social support. American Journal of Sociology, 96, 558-588.

\section{Over de auteurs}

Sarah Westphal is als promovendus verbonden aan de vakgroep Sociologie van de Universiteit Utrecht. Dit artikel is een bewerking van haar Masterthesis voor de onderzoeksmaster Sociology and Social Research.

Correspondentieadres: Sarah Westphal, Vakgroep Sociologie, Universiteit Utrecht, Postbus 810140, 3508 Tc Utrecht. Email: s.k.westphal@uu.nl. 
Gerald Mollenhorst is als universitair docent en onderzoeker verbonden aan de vakgroep Sociologie van de Universiteit Utrecht en tevens als onderzoeker aan de vakgroep Sociologie van de Universiteit van Stockholm in Zweden.

Beate Völker is als hoogleraar verbonden aan de vakgroep Sociologie van de Universiteit Utrecht. 